\title{
THE USE OF MEMORY ENGLISH LEARNING STRATEGIES OF THE STUDENTS AT THE FACULTY OF ECONOMICS IN KRAGUJEVAC
}

\author{
Marijana D. Matić*
}

The paper investigates the use and frequency of memory language learning strategies in learning English of students of the Faculty of Economics at Kragujevac University. Taking into consideration the importance of using English in their future careers, a total of 146 students at first and second year of learning English at the Faculty of Economics in Kragujevac were researched. The respondents filled in the Strategy Inventory for Language Learning (SILL) and a Background Characteristics Survey. The results of the types of memory strategies and their frequency are presented. The aim of the research is also to provide information about the use of memory strategies both to university students in general and their teachers which would help improve their use of English.

Keywords: language learning strategies, SILL, memory strategies, the English language, students at university level, quantitative research.

\section{INTRODUCTION}

Taking into consideration the fact that to a greater or smaller extent we are all a part of the Global labour market, it is sensible to conclude that knowing English and using it on daily basis in different forms of communication plays an important part for adults, especially students of Economics and future economists. For that reason we have decided to look into the English language

* University of Kragujevac, Faculty of Philology and Arts; Contact:

marijuana.matic@filum.kg.ac.rs 
learning strategies of the students of the Faculty of Economics, Kragujevac University, namely the memory strategies.

The aim of this paper is to investigate the frequency and use of memory learning strategies of English by students at tertiary level of education, at the Faculty of Economics, University of Kragujevac and to provide information about the use of these strategies to both students and their teacher. We believe and are supported by other research that this information can help students to understand their learning process.

We are also of the opinion that teaching language learning strategies to teachers of English at tertiary level should be taken into consideration (and among them the memory strategies as well), as different research has also indicated that language learning strategies can be closely associated with learners' language performance and achievements (Bremner, 1999: 493; Oxford, 1990:21). If the foreign language teachers are well informed about the importance of and skilled at language learning strategies, we believe they can recognize the strategies their students use, misuse or underuse and thus not only adapt their teaching but also teach students about the value and span of LLS they can use.

In order to come up with the scope of language learning strategies different research has looked into what distinguishes good language learners from poor language learners. Along those lines good language learners have been defined as those who adopt strategies to make their learning more effective (Rubin, 1981: 45-47). Moreover, it is stated that, if the aim of any education, and thus also of tertiary education are independent, self-directed, life-long learners ${ }^{1}$ it is sensible to conclude that teaching about strategies can improve students learning. As evidence shows teaching about the strategies can improve students' learning. The aim is not only for the students to improve their learning but the long-term goal for them as independent, long-life learners to be able to recognize the strategies themselves and use them to an extent satisfactory to their learning. Based on all that, the aim of this paper is also to offer valuable information to teachers about the learning strategies of their students, to show the importance of teaching language learning strategies and to suggest teaching them their students.

In order to investigate memory English learning strategies of students of Economics, we have used Oxford's Strategy Inventory for Language Learning

1 Su (2005: 49) 
(SILL), published in 1990. Apart from the questionnaires used the students also filled a questionnaire considering their background information which was used to get insight into students and their experience of learning English and other demographic data.

\section{LANGUAGE LEARNING STRATEGIES}

Language learning strategies first started to be researched in the 1960s (with Aaron Cartons first publication in 1966). During these first stages of research strategies were defined as particular behaviours conducted by learners in the learning situation.

The interest in language learning increased during the 1970s during which the cognitive perspective in psychology emerged. Its aim was to explain cognitive processes in language learning; so the first studies in language learning of this period analyzed and described the external behaviours of language learners (Zare, 2012:124). These studies also tried to find different categories of strategic behaviours and tried to classify them, with the aim to link the strategic behaviours and language proficiency (ibid).

\subsection{Definition of Language Learning Strategies}

Since 1960s and the beginng of interest in language learning strategies all the research and thinking about them have attempted at giving insight into what learners think and do during language learning. The phenomenon of LLS has undergone many changes. Some definitions of LLS aimed at including both linguistic and sociolinguistic aspects of foreign language learning (Faerch, Claus and Casper, 1983:23), whereas others tried to split the strategies into smaller elements such as: „...steps, operations, plans and routines which learners use in order to make the access, storage and use of the information easier" (Wenden and Rubin, 1987: 17). Cohen (1990:29) pointed out that "... learning strategies are consciously selected processes by learners which may result in actions taken to improve the learning or use of a second or foreign language through the storage, retention, recall, and application of the information about language."

Oxford (1990) expanded the previous definitions in a way. She stressed that context is essential in the language learning process. According to her language learning strategies are: "...specific actions which learner takes and 
thus make the learning easier, faster, more enjoyable, more self-directed, more effective, and more transferable to new situations."

These definitions of language learning strategies were followed by definitions which focus on learner's processes when acquiring a language. They all concentrated on learners' conscious intentions and behavior which would "... help them understand, learn or remember the necessary information better (Richards and Platt, 1992: 378)". The classroom in turn was perceived as a replica of a problem solving situation (Stern, 1992: 35) in which learners are expected to find the quickest solutions in order to successfully do a task. Since this knowledge is necessary in ever day situations, the use of language learning strategies was considered to be absolutely necessary whether they were used consciously or unconsciously.

The definition of language learning strategies can also be found in The Common European Framework (2001). What is pointed out in the document is the link between strategies and effective communication. Strategies are considered to be „,... a means for the language user to exploit in order to fulfill the demands of communication in context and successfully complete the task in question in the most comprehensive or most economical way possible for a precisely defined purpose".

\subsection{Oxford's Classification of Language Learning Strategies}

According to Oxford (1990) whose classification of language learning strategies we have adopted for the research instrument in this paper, language learning strategies are oriented towards the development of communicative competence. She divided them into two main groups, direct and indirect strategies, which are in turn subdivided into six groups. The direct strategies are defined as those which involve new language directly and are classified into memory, cognitive and compensation strategies. According to Oxford all direct strategies require mental processing of the language (p. 37). Indirect strategies include meta-cognitive, affective and social strategies. They all provide indirect support for language learning. Memory strategies as defined by Oxford:

"...involve the mental processes for storing new formation in the memory and for retrieving them when it is necessary. ...These strategies include four sets: creating mental linkages, applying images and sounds, reviewing well and employing action"(ibid). 
In this paper we make use of Oxford 's (1990) Strategy Inventory for Language Learning (SILL). It is an instrument in the form of a questionnaire designed for assessing the frequency of use of language learning strategies by students. In this research we have used the one for learners of English as a foreign language, in particular the first nine questions of the questionnaire concerning memory strategies.

These SILL items are evaluated on an increasing five point Likert scale which ranges from one to five. The number indicates how often the learner uses the strategies:

$1=$ never or almost never true of me

2 = generally not true of me

$3=$ somewhat true of me

$4=$ generally true of me

$5=$ always true of me

The average scores of 3.5-5.0 on a 5-point Likert scale are considered as high use, those of 2.5-3.4 as medium use and those of 1.0-2.4 as low use (Oxford, 1990:42 and $\mathrm{Su}, 2005: 45)$.

\subsection{The Value of Language Learning Strategies and Implications on Learners and Teachers}

It has been found that what distinguishes good language learners from the poor ones is not so much which strategies they use, but more the flexibility they apply to the use of language learning strategies. According to McDonough the success of good language learners also lies in the fact that they use the strategies more frequently and more properly than the poor ones (McDonough, 2006: 64). The research has also shown that some learners have become more successful because they are aware of the fact that different language tasks require different strategies, so they apply specific strategies to specific tasks; and what is more, they know better how to combine different strategies when necessary (Abraham and Vann, cited in Oxford, 2001).

It was argued that the more we know about the LLS use by successful learners, the better we can teach them to the poor learners (Rubin, 1975: 28) which lead scientists to conclude that there exists "teachability" of LLS. This means that if we teach strategies to students they will in turn use them better and fulfill the tasks at hand more successfully. So we can conclude that if we 
teach the importance of strategies to teachers and help them include teaching about them to students the benefits will be multifold.

\subsection{Respondents and the research instrument}

A sample of 146 students in total first completed SILL (Oxford, 1990: 293-6). They all take English as a subject on the first and second academic year. English is an optional subject because there is also a choice of attending a Russian course at the beginner and elementary level and German at elementary level.

Apart from that students filled in the questionnaire B providing background information (enclosed at the end of the paper) about their previous experience of learning English as a foreign language, their reasons for choosing English at tertiary level, their knowledge about their level of English, their expectations and needs from the university course of English. Students have also responded to the question if they use applications for learning English and what they are mostly useful for.

\section{THE RESULTS}

\subsection{Background information about the respondents}

As previously stated, a sample of 146 students in total completed SILL (Oxford 1990: 293-6) and the questionnaire B. These were 30 male and 116 female students in total, out of which 16 male and 39 female students on the first year, and 14 male and 77 female students on the second academic year at the Faculty of Economics, University of Kragujevac.

A vast majority of students $(98.63 \%$ ) learned English in elementary and secondary school. This means that the vast majority of students have undertaken instructions in English for at least 12 years at the moment of research. During these 12 or so years, only $21.23 \%$ also took private classes which is less than $1 / 4$ of the total number. Out of this $1 / 4$ a little bit more than a half of students $(54.84 \%)$ took sporadic extra classes with the aim of getting better results at a test or getting a better grade in general. Only 10 students on both years (out of 146) took private classes which lasted longer than 6 months. This means that as learning English in the classroom setting is concerned, 
students were mainly engaged by official state school English lessons with sporadic additional help.

Apart from lessons at the university, it seems that very few students use applications to learn English, only 10 of them. 5 use Duolingo, and the others, 1 each, use English grammar test Olingo, BBC English, English speaker, Google translate, Speak English. They claim that those applications have helped them learn new vocabulary and grammar. However, the sample is limited by far to make any widely applicable conclusions.

The number of students who know their current level of English and have taken some international tests of English is also very small- only 6, and only 2 have Cambridge University Certificate for Learners of English as a foreign language at level B2 out of 146 students. A vast majority is also not interested in finding out their current level of English.

A total of $82.19 \%$ of students on both years chose to learn English (as opposed to Russian and German) because they would like to improve their area-specific knowledge of English which they consider important for their future profession. On average 10.96\% chose to learn English at university level because they think they possess certain knowledge and thus they will have success on the exam. $4.11 \%$ do not know why they chose English, and 1.37\% chose English because their friends had chosen it.

\subsection{The Use of Language Learning Strategies and the use of the Memory Strategy}

As far as the strategies used are concerned, the results show the following:

\begin{tabular}{|c|c|c|c|c|}
\hline & & First year & Second year & Both years \\
\hline \multirow{6}{*}{ 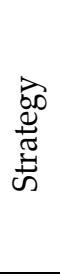 } & Part A (memory) & 2.75 & 3.00 & 2.91 \\
\hline & Part B (cognitive) & 3.15 & 3.05 & 3.09 \\
\hline & Part C (compensation) & 3.21 & 3.11 & 3.15 \\
\hline & Part D (meta-cognitive) & 3.64 & 3.39 & 3.48 \\
\hline & Part E (affective) & 2.54 & 2.77 & 2.68 \\
\hline & Part F (social) & 3.08 & 3.29 & 3.21 \\
\hline & Average & 3.06 & 3.10 & 3.08 \\
\hline
\end{tabular}

The use of all strategies on average does not exceed the medium use as defined by Oxford and Su. It can also be noticed that the memory strategies are used almost the least of all the strategies. The only less frequently used set of 
strategies is the affective strategies. There is a growth in the use of memory strategies in the second year of studies when compared with the first year. However, in both cases the frequency of the use of strategies does not exceed medium use.

In this paper we aimed at researching about the memory strategies so the frequency of answers to the memory strategies of both years of study by the students at the Faculty of Economics is presented in the following graphs.

In what follows is a detailed analysis of the SILL questionnaire concerning the memory strategies and our survey of the respondents' answers is presented.

Here are the results for the first memory strategy:

\section{Memory strategy 1 - I think of relationships between what I already know and new things I learn in English.}

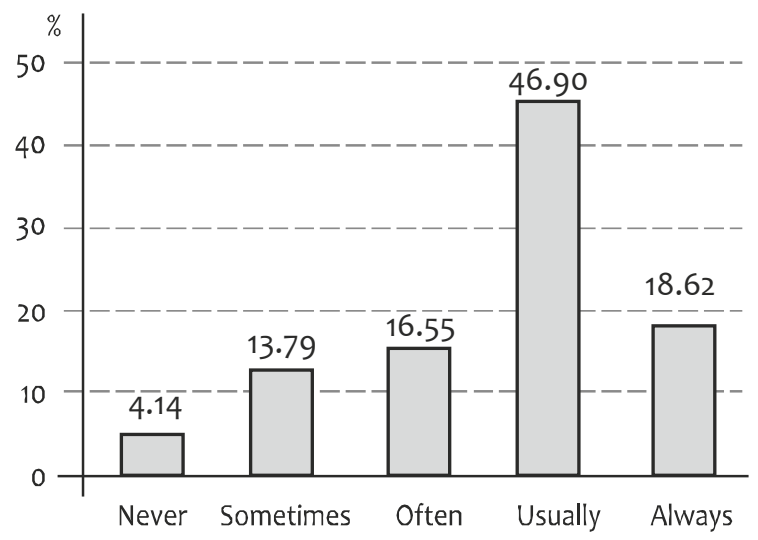

Almost half the students (46.90 \%) usually use this strategy in their learning English, whereas $18.62 \%$ always and $16.55 \%$ often use it. It can be observed that students to some extent have the awareness of what they have learned and try to make connections between the previously acquired information and new information in different areas of language- grammar and vocabulary for example; which can in turn lead to long-term memory and better overall outcomes in using English as a foreign language. 


\section{Memory strategy 2: I use new English words in a sentence so I can remember them}

Almost half of the students usually use the newly acquired words to make a sentence, and almost another quarter sometimes do so. Only $16.55 \%$ say they always use this strategy and $15.17 \%$ of students often use it. Using the new words by making a sentence helps students understand how to use them in context which is very important for their later use and can in turn also help students feel that the world can be useful for them in the future.

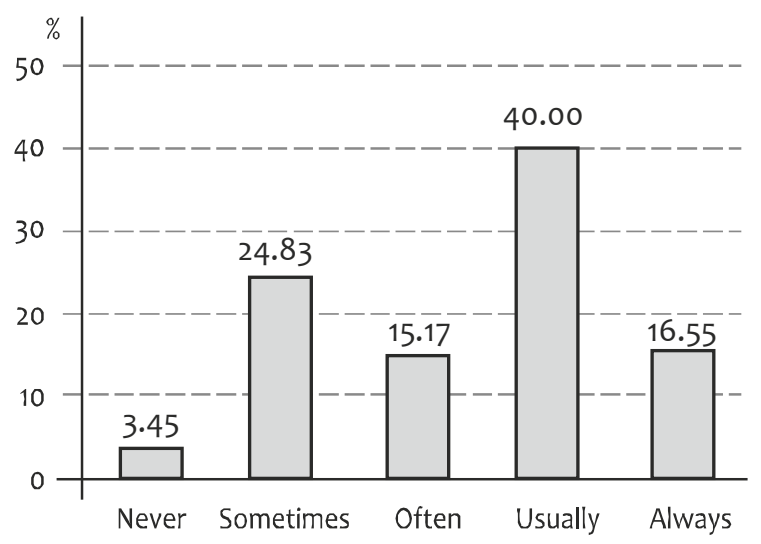

According to some scientists the frequency of this language learning strategy among the respondents could also be related to the activities present in textbooks (Arellano, 2017:239), as they believe there is still a prevalence of grammar-oriented activities and rather mechanical practice in the English learning textbooks.

\section{Memory strategy 3 - I connect the sound of a new English word and an image or picture of the word to help me remember the word.}

The connection of the words' pronunciation and an image of it is very useful for remembering it later. According to Coraps (2008) the lack of connection between the phonological and semantic word aspects reduces the adequate acquisition of vocabulary. This strategy seems to be popular with students of Economics. Namely, 37.23\% of students usually use it, with $23.45 \%$ who always use it and $21.38 \%$ who sometimes use it. 


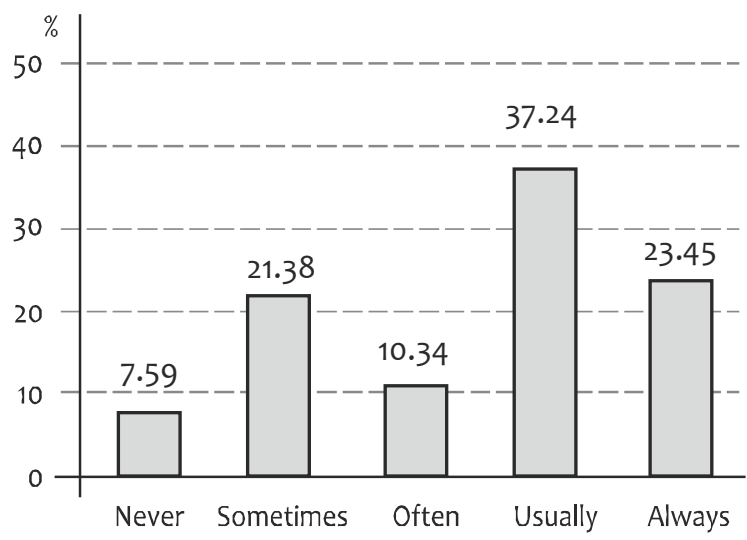

\section{Memory strategy 4 - I remember a new English word by making a mental picture of a situation of which the word might be used.}

It is interesting to compare the results for this memory strategy with those for the previous one. The mental image is not of a word or phenomenon it represents. Rather, it is of the situation where the word would be used. As we can notice that students tend to use this memory strategy less than the strategy 3 in almost all the frequencies. The number of students who never use it also rises. Only the number of students who never use this strategy rather than the previous one is bigger. However, according to the results, this strategy is also rather popular among the students of Economics.

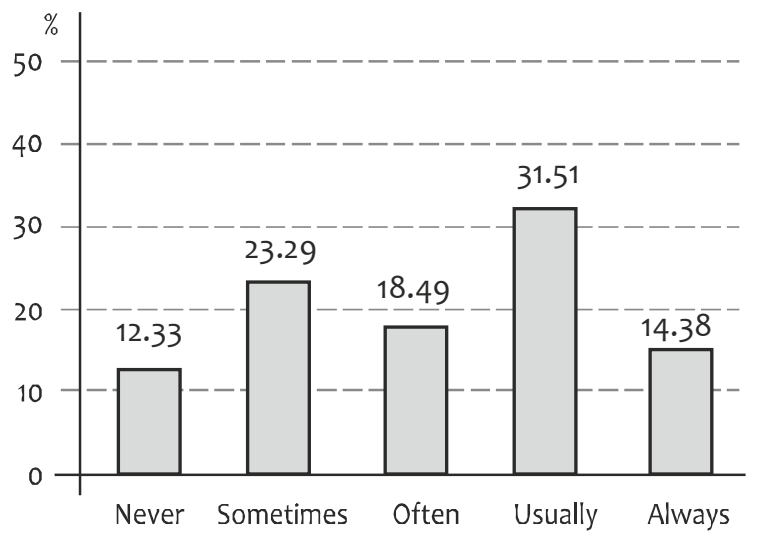


As Arellano (2017:241) $)^{2}$ points out, language learning activities which include making maps, charts, or graphs which represent semantic relations of words or concepts can also increase the language learning outcomes of those students. We believe that the students of Economics are used to graphs and charts in their economic subjects and can relate that knowledge and understand the value of such techniques in language learning as well.

\section{Strategy 5 - I use rhymes to remember new English word.}

This strategy is not very popular among the students of Economics as 37 . $67 \%$ of them never use rhyme to memorize the words. $30.82 \%$ of students claim to use this strategy sometimes whereas $17.81 \%$ usually use it. The number of students who always use it is $6.85 \%$. The students with auditory learning style can benefit from using this strategy.

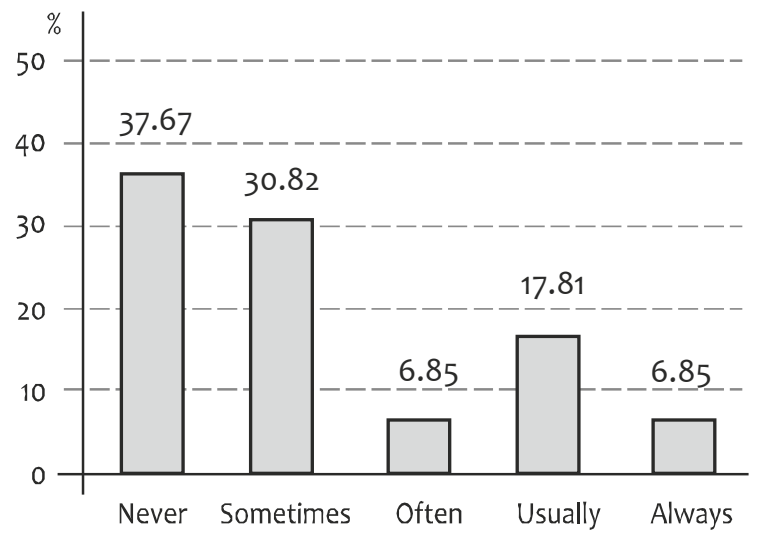

It seems that students are not aware of the power of pairs of words rhyming and attach rhyming to poetry or to techniques used by children rather than adults. Bearing in mind the complexity of English spelling, we consider it important to point out to this strategy as the number of homophones among frequently used words in English is rather large.

2 Arellano (2017) conducted a similar research on memory strategies in vocational studies of students in Hungary, Spain and Italy. 


\section{Strategy 6 - I use flashcards to remember new English words.}

This strategy seems to be the least popular of all among the students of Economics. As can be seen from the graph, over half of the students (55.56\%) never use any flashcards in order to help them remember the words, and $22.92 \%$ use them sometimes. This is probably due to the fact that students attach this teaching / learning technique to learning English as children and do not consider it to be a language learning strategy. Very few students have stated that they use this technique on regular basis. It would be an interesting to investigate further as to get a more detailed information which flashcards they sometimes use: the ones the teacher brings to class (which we believe is highly unlikely), the ones accompanying the textbook or the ones they make themselves or other.

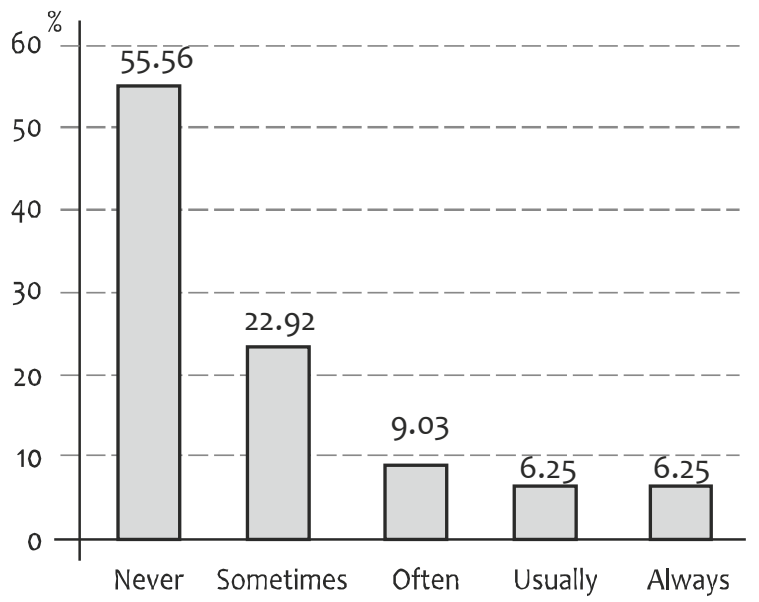

Arellano is of the opinion that although texbooks for secondary education (and this could be, we believe, applied to tertiary education in Serbia as well) are visually attractive, they do not normally offer "...an image glossary or flashcards to foster visual links." (Arellano, 2017:242)

\section{Strategy 7 - I physically act out new English words.}

Almost half of the students (42.6\%) state they never physically act out new words in English, whereas $25.69 \%$ sometimes use this technique. However, $17.36 \%$ students claim to usually use it. 


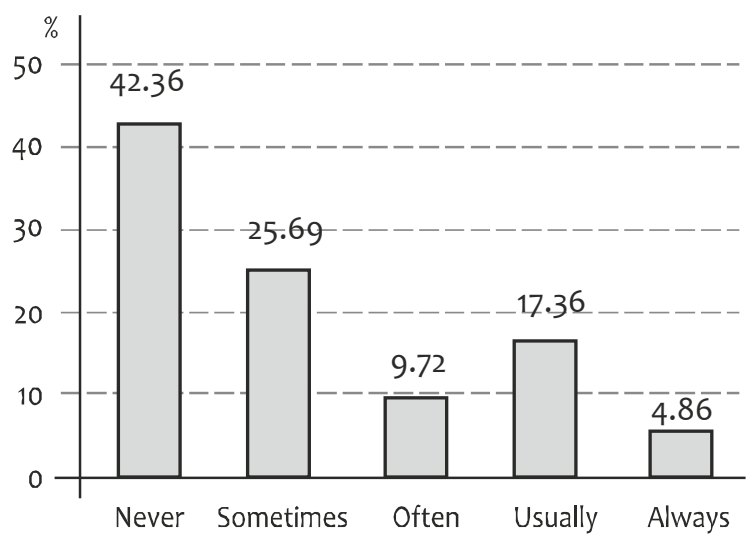

This language learning strategy is also not very popular among the students of Economics although kinesthetic learners could benefit from it. We believe that it is considered to be a teaching / learning technique typical for learning at a young age. The acting out is probably perceived as childish and thus partly unacceptable for the respondents and gestures, mime and acting are probably not considered to be a part of a memory learning strategy which has any value. We strongly believe that role play can be a technique all students of different ages and levels can benefit from and thus new words (among other benefits) could be acquired more successfully by using this technique.

\section{Strategy 8 - I review English lessons often.}

The answers to the use of this strategy are divided into three $1 / 4$ by the frequencies of sometimes, often and usually, whereas the two far ends of the frequency-always and never together make up for the final quarter. Thus 70. $55 \%$ of students more ore less frequently revise the lessons in English. As it is a generally known fact, revision is highly important as it enables language learners to assimilate, restore and retrieve information and in the long run leads to long-term memory. We wonder, however, if the resopndents in reality revise English lessons to this extent, or if this was felt to be a rather socially acceptable answer by students. 


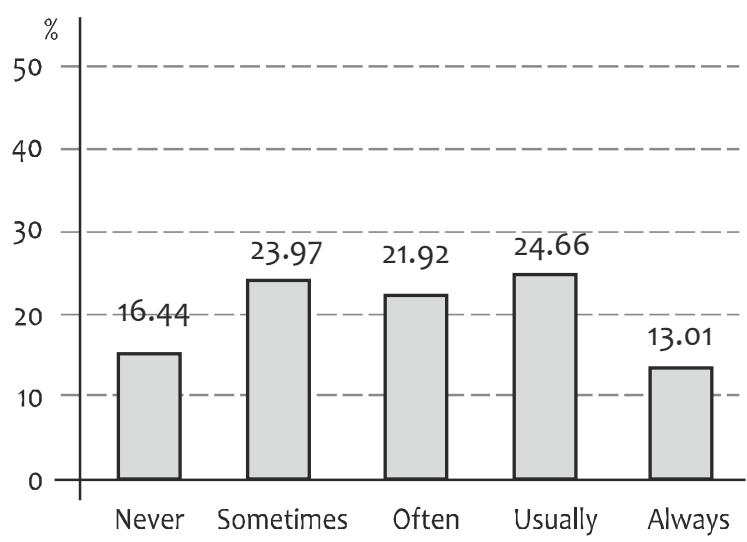

Strategy 9 - I remember new English words or phrases by remembering their location on the page, on the board, or on a street sign.

As can be noted $35.62 \%$ of the students admit that they usually remember new words or phrases by remembering their location, whereas $19.86 \%$ always do it. The remaining $18.94 \%$ sometimes do it and $13.01 \%$ often do it. This leaves us with only $13.01 \%$ who never do it. It can be concluded that the vast majority of students of Economics are visual learners. They can be helped in their learning by images, pictures, graphs and spatial organization of different elements.

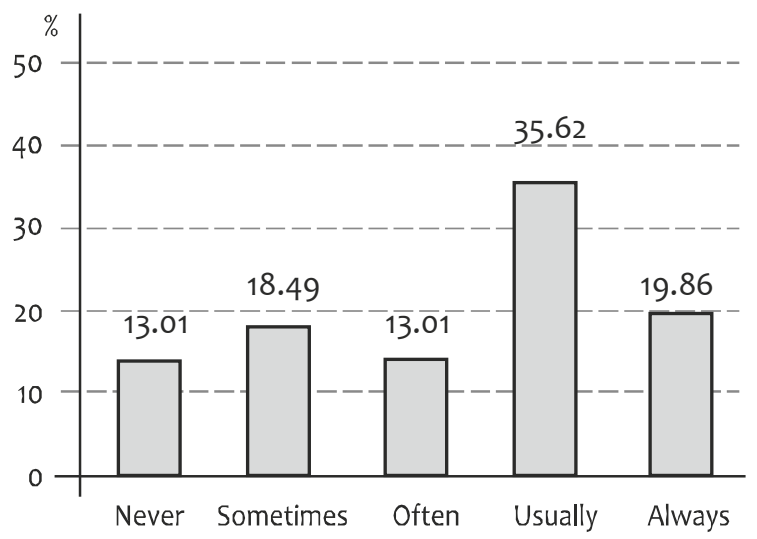




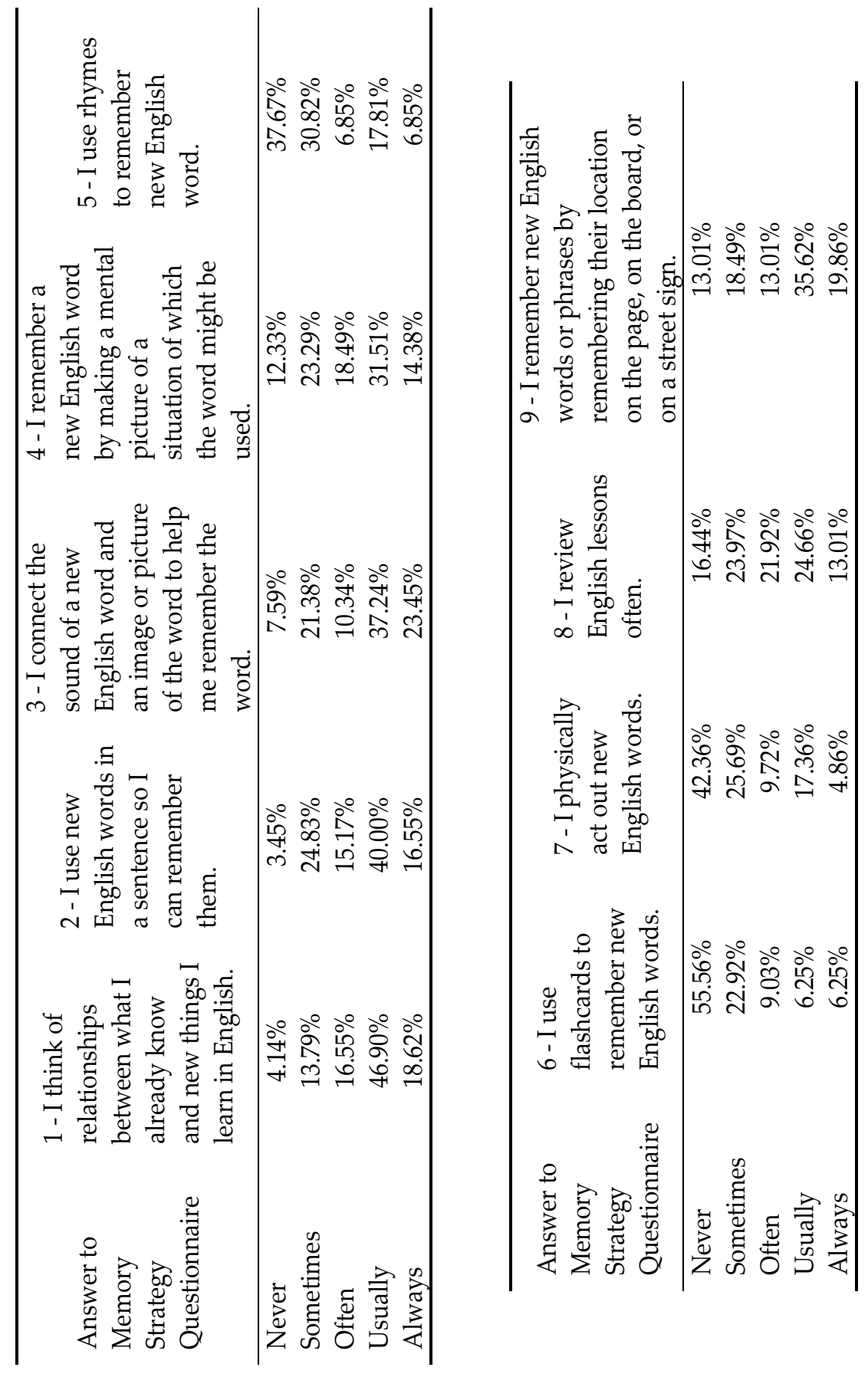


As can be noticed the memory strategy which is always used by the students and has the highest percentage is I connect the sounds of a new English word and an image or picture of the word to help me remember the word $(23.45 \%)$ followed by I remember new English words or phrases by remembering their location on the page, on the board, or on a street sign $(19.86 \%)$. These two strategies show how important for the students of Economics is the visual learning style. This can help both teachers and students during the education process.

The memory strategies which are used usually by the students presented from the highest to the lowest are I think of relationships between what I already know and new things I learn in English (46.90\%), I use English words in a sentence so I can remember them $(40.00 \%)$, I connect the sounds of a new English word and an image or picture of the word to help me remember the word (37.34\%), I remember new English words or phrases by remembering their location on the page, on the board, or on a street sign $(35.62 \%)$ followed by I use rhymes to remember new English word (17.81\%) and I physically act out new English words (17.36\%).

When it comes to the strategies which are used often it is interesting to notice that only the strategy I review English lessons often exceeds 20\% -21.92\%. The rest are used within the range from $9.03 \%$ to $18.49 \%$.

As far as the memory strategies used sometimes are concerned, I use rhymes to remember new English word was given 30.82\% which means that within this range it is the least often used followed by almost all the rest and their use ranging from $25.69 \%$ (I physically act out new English words) to $21.38 \%$ (I connect the sounds of a new English word and an image or picture of the word to help me remember the word). In the case of the strategy I physically act out new English words, its highest frequency is never and the same goes for I use flashcards to remember new English words. The rest of the strategies are used more often-often, usually or always. Only $13.79 \%$ of students sometimes use the strategy I think of relationships between what I already know and new things I learn in English. It seems to be the most popular strategy among the students.

When it comes to the strategies never used the two least popular strategies with the highest score in this range are I use flashcards to remember new words (55.56\%) and I physically act out new English words (42.36\%) followed by I use rhymes to remember new English word (37.67\%). 


\section{INTERPRETATION OF THE RESULTS AND CONCLUSION}

Students at the Faculty of Economics in Kragujevac have shown interesting results in this research considering the use of memory language learning strategies. The vast majority of students are female students, whereas male student make up $20.5 \%$ of the total population which was investigated. The length of official learning of English is 12 years or more and the majority of students have not found it necessary to expand their knowledge in additional lessons or to be informed about their current level of English. Despite the availability of applications to check, improve, learn English, very few students have shown interests to do so. Out of those few, most mainly to learn new vocabulary and / or grammar.

The most significant result seems to be the fact that the language learning strategies are used only to a medium level. When it comes to memory language learning strategies they are one but least frequently used strategies. Only affective strategies are used to an even lesser extent. The most frequently used among the memory strategies are I think of relationships between what I already know and new things I learn in English, I use English words in a sentence so I can remember them, I connect the sounds of a new English word and an image or picture of the word to help me remember the word and I remember new English words or phrases by remembering their location on the page, on the board, or on a street sign. The strategies frequently used by the students at the Faculty of Economics in Kragujevac can partly be explained by learning styles (visual and auditory), but what can be important for the teachers to know is that students actively make connections between their previous and newly acquired knowledge so the use of mind maps, graphs and other mental aids which can help make connections would be very useful. Apart from that learning vocabulary by using sentence context can be valuable in the teaching / learning process. The same would apply to grammar rules and learning the language in general.

The memory strategies which are not favourite with the students of Economics are: I use flashcards to remember new words, I physically act out new English words and I use rhymes to remember new English word. It seems that students do not consider them valuable and perhaps even consider them typical of children learning English rather than adults. 


\section{Limitations and delimitations of the study}

The research was performed in quantitative manner. It showed valid results which can be further analyzed by the means of qualitative instruments, openended interviews or focus group discussions.

\section{The Conclusion and Further Recommendations}

It is clear that the memory language learning strategies are underused by the students of the Faculty of Economics in Kragujevac. It is advisable for the teachers to teach such strategies to students and to adapt their teaching in order to make use of the strategies already used in order to make learning more effective.

\section{REFERENCES}

Arellano Corpas D, (2017). Memory learning strategies in English as a foreign language in vocational studies. Tendencias Pedagogicas, 29, 229-248

Bremner, S. (1999). Language learning strategies and language proficiency: Investigating the relationship in Hong Kong. Canadian Modern Language Review, 55(4), 490-514.

Carton A. S. (1966). The Method of Inference in Foreign Language Study. City University of New York. Division of Teacher Education. City University of NewYork. Research Foundation

Cohen, A. (1990). Language learning: Insights for learner, teachers and researchers. New York. Newbury House.

Council of Europe (2001). Common European Framework of Reference for Languages: Learning, Teaching, Assessment. Cambridge: Cambridge University Press.

Faerch, C. and G. Kasper (1983). Strategies in Interlanguage Communication. London: Longman.

McDonough, K. 2006. Responses to recasts: Repetitions, primed production, and linguistic development. Language Learning, 693-720. Blackwell Publishing Inc.

Oxford, R.L. (1990) Language learning strategies: What every teacher should know. New York: Newbury House / Harper and Row.

Oxford, R.L. 2001. "Language Learning Strategies" in Carter, R. and Nunan, D. (eds.) The Cambridge Guide to Teaching English to Speakers of Other Languages. Cambridge: Cambridge University Press 
Richards, J and John Platt (1992). Longman Dictionary of Language Teaching and Applied Linguistics. Essex: Longman.

Rubin, J. 1975. What the "Good Language Learner" can teach us. TESOL Quarterly 9/1: 41-51. TESOL International Association.

Stern, H. H. (1975). Issues and Options in Language Teaching. Oxford: OUP.

$\mathrm{Su}, \mathrm{M}$. (2005). A study of EFL technological and vocational college students' language learning strategies and their self-perceived English proficiency. Electronic Journal of Foreign Language Teaching, 2(1), 44-56.

Wenden, A. and Rubin, J. 1987. Learner strategies in language learning. Prentice Hall International.

Zare, P., Nooreen, N. (2010). An Investigation into language Learning strategy use and gender among Iranian undergraduate language learners. World Applied Sciences Journal, 11 (10): 1238- 1247. 
Pезиме

\section{КОРИШЋЕЊЕ СТРАТЕГИЈЕ ПАМЋЕЊА У УЧЕЊУ ЕНГ ДЕСКОГ ЈЕЗИКА КОД СТУДЕНАТА ЕКОНОМСКОГ ФАКУ ЛТЕТА У КРАГУЈЕВЦУ}

Циљ овог рада је истраживање учесталости и употребе стратегија учења језика на универзитетском нивоу. Имајући у виду да је квалитет учења енглексог језика на универзитетском нивоу важан студентим због њиховог професионалног живота у којем се од њих очекује да користе енглески, као и да примењују стратегије учења језика како би постали они који се баве доживотним образовањем, подузели смо истраживање стратегија учења на популацији студената Економског факултета, Универзитета у Крагујевцу. Вредност резултата овог истраживања састоји се у томе да се баци светло на ниов и врсту стратегија учења страног језика које се користе на универзитетском нивоу. Ова сазнања могу да помогну студентима и њиховим професорима да користе / науче како да се користи енглески језик на учнковитији начин како би студенти унапредили своја знања бавећи се својим професијама у будућности.

Къучне речи: стратегије учења језика, ИСУЈ, енглески језик, студенти факултета, квантитативно истраживање 